\title{
Air Pollution Is Associated with COVID-19 Incidence and Mortality in Vienna, Austria
}

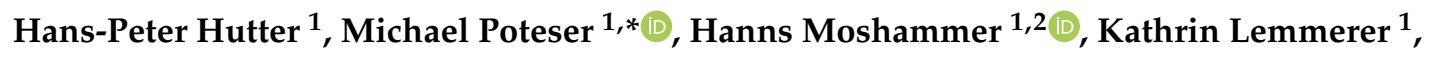 \\ Monika Mayer ${ }^{3}$, Lisbeth Weitensfelder ${ }^{1}$, Peter Wallner ${ }^{1}$ and Michael Kundi ${ }^{1}$ (D) \\ 1 Center for Public Health, Department of Environmental Health, Medical University of Vienna, 1090 Vienna, \\ Austria; hans-peter.hutter@meduniwien.ac.at (H.-P.H.); hanns.moshammer@meduniwien.ac.at (H.M.); \\ kathrin.lemmerer@meduniwien.ac.at (K.L.); lisbeth.weitensfelder@meduniwien.ac.at (L.W.); \\ peter.wallner@meduniwien.ac.at (P.W.); michael.kundi@meduniwien.ac.at (M.K.) \\ 2 Department of Hygiene, Medical University of Karakalpakstan, Nukus 230100, Uzbekistan \\ 3 Institute of Meteorology and Climatology, University of Natural Resources and Life Sciences Vienna, \\ 1180 Vienna, Austria; monika.mayer@boku.ac.at \\ * Correspondence: michael.poteser@meduniwien.ac.at; Tel.: +43-1-40160-34915
}

Received: 13 October 2020; Accepted: 9 December 2020; Published: 11 December 2020

\begin{abstract}
We determined the impact of air pollution on COVID-19-related mortality and reported-case incidence, analyzing the correlation of infection case numbers and outcomes with previous-year air pollution data from the populations of 23 Viennese districts. Time at risk started in a district when the first COVID-19 case was diagnosed. High exposure levels were defined as living in a district with an average (year 2019) concentration of nitrogen dioxide $\left(\mathrm{NO}_{2}\right)$ and/or particulate matter (PM10) higher than the upper quartile (30 and $20 \mu \mathrm{g} / \mathrm{m}^{3}$, respectively) of all districts. The total population of the individual districts was followed until diagnosis of or death from COVID-19, or until 21 April 2020, whichever came first. Cox proportional hazard regression was performed after controlling for percentage of population aged 65 and more, percentage of foreigners and of persons with a university degree, unemployment rate, and population density. PM10 and $\mathrm{NO}_{2}$ were significantly and positively associated with the risk of a COVID-19 diagnosis (hazard ratio $(\mathrm{HR})=1.44$ and 1.16, respectively). $\mathrm{NO}_{2}$ was also significantly associated with death from COVID-19 (HR = 1.72). Even within a single city, higher levels of air pollution are associated with an adverse impact on COVID-19 risk.
\end{abstract}

Keywords: COVID-19; PM10; $\mathrm{NO}_{2}$; spatial air pollution differences; incidence; mortality

\section{Introduction}

Air pollution has been linked to an increased risk of respiratory infections (see reviews by Ciencewicki and Jaspers [1], Domingo and Rovira [2]). With regard to the epidemic of SARS-CoV in 2003, an ecological study from China reported case fatality rates to be higher in regions with higher air pollution, as measured by the Air Pollution Index (API) [3]. However, in another study the outbreak of SARS-CoV in mainland China was found to be not related to API [4]. Kan et al. [5] found daily SARS-CoV-2 mortality associated especially with nitrogen dioxide $\left(\mathrm{NO}_{2}\right)$.

Based on these initial findings, a possible causal association between air pollution and COVID-19 mortality has been debated. Conticini et al. [6] argued that the high level of air pollution in Northern Italy could be a cofactor for the higher COVID-19 prevalence and mortality in this region by weakening the upper airways' defense and leading to chronic inflammation. Ogen [7] investigated COVID-19 fatality rates in 66 administrative regions in Italy, Spain, France, and Germany in relationship to long-term $\mathrm{NO}_{2}$ concentrations. Most of the fatalities were found in the regions with the highest $\mathrm{NO}_{2}$ concentrations. Another ecological study [8] reported an association between long-term exposure to 
particulate matter $\left(\mathrm{PM}_{2.5}\right)$ and COVID-19 incidence in Canada. Highly significant correlations between $\mathrm{PM}_{2.5}$ concentrations and COVID-19 incidence, mortality, and case fatality rates were also shown for the Italian provinces [9]. Moreover, the role of PM in the spread of COVID-19 was emphasized in a review focusing on Italian cities [10]. A systematic review of 15 studies concluded that especially $\mathrm{PM}_{2.5}$ and $\mathrm{NO}_{2}$ are contributing to COVID-19 spread and lethality [11].

Villeneuve and Goldberg [12] recently analyzed the methodology of epidemiological studies investigating the association between air pollution, and SARS and COVID-19 coronavirus outbreaks. They pointed out uncertainties because of possible exposure measurement error and residual confounding.

While a single study is always prone to error, multiple studies undertaken in different settings and at different scales allow for a more holistic appraisal of the environmental impact of air pollution on infection risk. Due to these considerations, we set out to investigate whether in a large city such as Vienna, with a known variance of air pollution across districts, an association with local incidence and mortality of COVID-19 can be found. Vienna has 23 districts that range from green spaces close to Vienna Forest to areas with industry and heavy traffic. We obtained daily numbers of cases and deaths for each of these districts and district-wide air pollution data for the year 2019 as indicators of chronic exposure. Daily incidence and mortality were analyzed by Cox regression considering district data of population attributes as confounders.

\section{Materials and Methods}

\subsection{Epidemiological and Demographic Data Sources}

The analysis was based on daily reported COVID-19 cases and deaths collected at the epidemiological documentation system of the Vienna Health Authority until 21 April (after peak of infections), 2020. The first diagnosis of COVID-19 in Vienna was reported on 28 February 2020. A first fatality was attributed to COVID-19 in Vienna on 11 March 2020. New infections were reported with the date of first diagnosis or death, and the district of residence. The city of Vienna, with a total population of 1,893,779 as of 31 October 2018, consists of 23 districts. Population numbers for each district were extracted from Statistics Austria general population data sets [13], and population density was calculated using municipal district data. Sociodemographic data per district retrieved included: percentage of persons aged 65 or above, percentage of foreigners, unemployment rate, and percentage of persons with a university degree.

\subsection{Air Pollution Data Sources}

The European Environment Agency (EEA) collects and provides data sets of specific pollutant concentrations of all EU member states. Nitrogen dioxide $\left(\mathrm{NO}_{2}\right)$ and particulate matter $\left(\mathrm{PM}_{10}\right.$ and $\mathrm{PM}_{2.5}$, particulate matter which passes through a size-selective inlet with a $50 \%$ efficiency cutoff at $10 \mu \mathrm{m}$ or $2.5 \mu \mathrm{m}$ aerodynamic diameter, respectively) data sets for all Viennese sites for the year 2019 were retrieved from the EEA's database on 13 March 2020. From these data sets, the annual average levels of $\mathrm{NO}_{2}$ and $\mathrm{PM}_{10}$ were calculated, based on daily mean values from sites with at least $75 \%$ data availability. Although the city of Vienna operates a dense air quality monitoring network consisting of 17 sites [14], observations are not carried out in each of the 23 urban districts. Thus, we estimated district level $\mathrm{NO}_{2}$ and $\mathrm{PM}_{10}$ annual means via a representative-site approach, based on spatial proximity of districts to observational sites and results from previous Differential Optical Absorption Spectroscopy (DOAS) measurements of $\mathrm{NO}_{2}$ in Vienna [15]. Schreier et al. 2019 [15] investigated the correlation between the car DOAS zenith sky measurements and the in situ observations from the air pollution monitoring network in Vienna. They found both measurements to be highly correlated $(\mathrm{R}=0.4)$. Retrospective data for years earlier than 2019 revealed declining trends, but districts with high exposures in 2019 also displayed high exposures in the previous years. Ranking between districts was less constant among the districts with lower average $\mathrm{NO}_{2}$ concentration. Therefore, we examined the effect of living in a 
district with high pollution (binary exposure variable). Because representative measurements could not be obtained for $\mathrm{PM}_{2.5}$ for all districts, analyses were based on $\mathrm{NO}_{2}$ and $\mathrm{PM}_{10}$ only.

\subsection{Statistical Analysis}

During the observation period, Austria entered a period of restricted social interactions (lockdown). Most shops and all restaurants and schools were closed, and people were encouraged to work in home offices and abstain from traveling. The introduction of SARS-CoV-2 into a district was considered a random event. Residents of that district were assumed to be at risk of acquiring COVID-19 or of dying with a diagnosis of COVID-19 beginning with the date when the virus was introduced into the district. Thus, a Cox proportional hazard model was built based on all residents of each district at risk, beginning at the date of the first diagnosed case in that district, and they were followed until diagnosis or death, or until the end of the observation period (21 April 2020), whichever came first.

Average air pollution concentration $\left(\mathrm{NO}_{2}, \mathrm{PM}_{10}\right)$ in those districts in 2019 was assumed to be the independent factor of interest; population density, percentage of persons aged 65 or above, percentage of foreigners, unemployment rate, and percentage of persons with a university degree were included in the model as possible confounders. As for some districts, $\mathrm{NO}_{2}$ and $\mathrm{PM}_{10}$ concentrations could only be estimated, air pollution concentration was entered as a binary variable equal or above versus below the upper quartile of all districts $\left(20 \mu \mathrm{g} / \mathrm{m}^{3}\right.$ for PM10, $30 \mu \mathrm{g} / \mathrm{m}^{3}$ for $\left.\mathrm{NO}_{2}\right)$.

\section{Results}

The first COVID-19 case was diagnosed on February 28 in the 22nd district. The last district to report a case was the 6th district on March 19. In the observation period, case numbers as well as the local hazard rate (considering the time of first case in district) were found to be different in districts of Vienna (Figure 1). COVID-19 deaths did not occur in all districts within the observation period. Overall, 1665 cases and 59 deaths were reported during the observation period, the first on March 21 in the 2nd district.

Additional area level factors were chosen a priori, driven by availability and existing evidence from the literature $[16,17]$. Indeed, some factors showed some correlation with air pollution levels, rendering them possible confounders (Table 1).

Table 1. Cross-correlation between predictors (upper triangle Pearson correlation, lower triangle Spearman correlation). Correlations with a coefficient of determination $>10 \%$ highlighted in bold.

\begin{tabular}{|c|c|c|c|c|c|c|c|}
\hline & $\begin{array}{c}\mathrm{PM}_{10}>20 \\
\mu \mathrm{g} / \mathrm{m}^{3}\end{array}$ & $\begin{array}{c}\mathrm{NO}_{2}>30 \\
\mu \mathrm{g} / \mathrm{m}^{3}\end{array}$ & $\begin{array}{c}\text { Percent } \\
\text { Aged 65+ }\end{array}$ & $\begin{array}{c}\text { Percent } \\
\text { Foreigners }\end{array}$ & $\begin{array}{c}\text { Unemployment } \\
\text { Rate }\end{array}$ & $\begin{array}{c}\text { Percent } \\
\text { University Degree }\end{array}$ & $\begin{array}{c}\text { Population Density } \\
\left(\text { per } \mathrm{km}^{2}\right)\end{array}$ \\
\hline $\mathrm{NO}_{2}>30 \mu \mathrm{g} / \mathrm{m}^{3}$ & 0.422 & & 0.160 & -0.132 & 0.056 & -0.127 & -0.216 \\
\hline Percent foreigners & 0.216 & 0.018 & -0.630 & & 0.526 & -0.097 & 0.613 \\
\hline Unemployment rate & 0.308 & 0.364 & -0.307 & 0.541 & & -0.861 & -0.042 \\
\hline Percent university degree & -0.226 & -0.386 & 0.121 & -0.085 & -0.847 & & 0.365 \\
\hline Population density (per $\mathrm{km}^{2}$ ) & 0.041 & -0.255 & -0.618 & 0.674 & -0.037 & 0.383 & \\
\hline
\end{tabular}

Air pollution levels measured as 2019 annual mean values of PM10 and $\mathrm{NO}_{2}$ did differ between districts (Table 2, Figure 2), allowing for a meaningful analysis. In the Cox regression, both air pollutants increased the risk for being diagnosed with COVID-19 (hazard ratio (HR) being 1.44 and 1.16 for the upper quartile of PM10 and $\mathrm{NO}_{2}$, respectively) and for dying with that diagnosis ( $\left.\mathrm{HR}=1.72\right)$; however, for COVID-19 deaths, only $\mathrm{NO}_{2}$ was statistically significant (Table 3). 


\section{COVID-19 hazard rate per 100,000
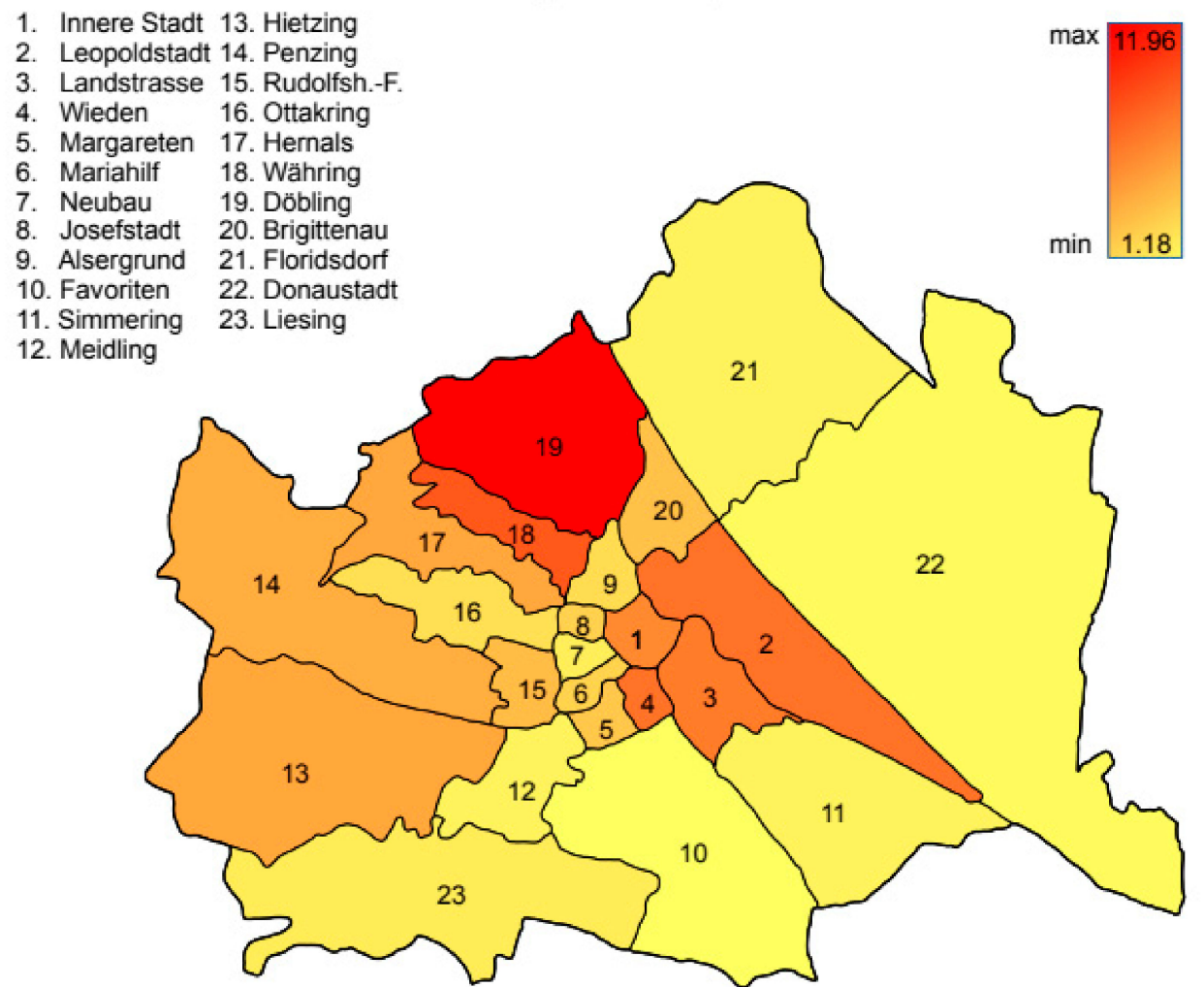
Table 2. Descriptive statistics of the 23 Viennese districts.

\begin{tabular}{ccccccc}
\hline District & $\begin{array}{c}\text { Population } \\
\text { Number } \mathbf{( N )}\end{array}$ & $\begin{array}{c}\text { Size } \\
\mathbf{( k m}^{\mathbf{2}} \mathbf{)}\end{array}$ & $\begin{array}{c}\text { Density } \\
\left(\mathbf{N} / \mathbf{k m}^{\mathbf{2}} \mathbf{)}\right.\end{array}$ & $\begin{array}{c}\text { Cases } \\
\mathbf{( N )}\end{array}$ & $\begin{array}{c}\text { Hazard Rate } \\
\text { per 100,000 }\end{array}$ & $\begin{array}{c}\text { Deaths } \\
\mathbf{( N )}\end{array}$ \\
\hline 1 & 16,306 & 2.86 & 5683 & 24 & 6.21 & 0 \\
2 & 104,946 & 19.23 & 5457 & 132 & 7.10 & 6 \\
3 & 91,745 & 7.39 & 12,402 & 80 & 6.72 & 3 \\
4 & 33,263 & 1.77 & 18,741 & 31 & 7.10 & 1 \\
5 & 55,407 & 2.01 & 27,551 & 31 & 3.52 & 0 \\
6 & 31,864 & 1.45 & 21,939 & 19 & 3.11 & 0 \\
7 & 32,288 & 1.60 & 20,121 & 22 & 1.93 & 0 \\
8 & 25,466 & 1.08 & 23,368 & 21 & 3.15 & 0 \\
9 & 41,958 & 2.96 & 14,142 & 39 & 2.69 & 1 \\
10 & 204,142 & 31.81 & 6416 & 133 & 1.18 & 4 \\
11 & 103,008 & 23.25 & 4430 & 71 & 1.66 & 3 \\
12 & 97,634 & 8.10 & 12,051 & 75 & 3.20 & 4 \\
13 & 53,778 & 37.70 & 1426 & 57 & 4.95 & 0 \\
14 & 92,990 & 33.75 & 2755 & 84 & 4.73 & 6 \\
15 & 77,621 & 3.92 & 19,786 & 73 & 4.04 & 0 \\
16 & 103,785 & 8.67 & 11,967 & 102 & 2.54 & 4 \\
17 & 57,292 & 11.38 & 5031 & 54 & 4.90 & 0 \\
18 & 51,587 & 6.34 & 8129 & 44 & 8.23 & 1 \\
19 & 72,947 & 24.94 & 2925 & 136 & 11.96 & 8 \\
20 & 86,502 & 5.70 & 15,153 & 69 & 3.80 & 2 \\
21 & 165,673 & 44.43 & 3728 & 146 & 1.67 & 8 \\
22 & 191,008 & 102.28 & 1867 & 147 & 1.38 & 6 \\
23 & 106,281 & 32.06 & 3315 & 75 & 2.01 & 2 \\
\hline Sum & $1,897,491$ & 414.79 & & 1665 & & 59 \\
\hline Mean & $82,499.60$ & 18.03 & 10799 & 72.39 & 4.25 & 2.56 \\
\hline
\end{tabular}

Table 3. Effect estimates from Cox regression model.

\begin{tabular}{clccccc}
\hline & \multicolumn{3}{c}{ SARS-CoV-2 Positive } & \multicolumn{3}{c}{ COVID-19 Death } \\
\hline & HR & \multicolumn{2}{c}{$95 \%$ CI } & HR & $95 \%$ CI \\
\hline $\mathrm{PM}_{10}>20 \mu \mathrm{g} / \mathrm{m}^{3}$ & $\mathbf{1 . 4 4}$ & $\mathbf{1 . 2 5}$ & $\mathbf{1 . 6 5}$ & 1.49 & 0.73 & 3.08 \\
$\mathrm{NO}_{2}>30 \mu \mathrm{g} / \mathrm{m}^{3}$ & $\mathbf{1 . 1 6}$ & $\mathbf{1 . 0 5}$ & $\mathbf{1 . 2 9}$ & $\mathbf{1 . 7 2}$ & $\mathbf{1 . 0 2}$ & $\mathbf{2 . 9 0}$ \\
Percent aged 65+ & 1.03 & 1.00 & 1.06 & 0.93 & 0.78 & 1.10 \\
Percent foreigners & 1.01 & 0.98 & 1.03 & 0.92 & 0.80 & 1.06 \\
Unemployment rate & $\mathbf{1 . 1 0}$ & $\mathbf{1 . 0 3}$ & $\mathbf{1 . 1 8}$ & 1.46 & 0.97 & 2.22 \\
Percent university degree & $\mathbf{1 . 0 5}$ & $\mathbf{1 . 0 3}$ & $\mathbf{1 . 0 7}$ & $\mathbf{1 . 1 4}$ & $\mathbf{1 . 0 1}$ & $\mathbf{1 . 2 8}$ \\
Population density (per km ${ }^{2}$ ) & $\mathbf{0 . 9 8}$ & $\mathbf{0 . 9 6}$ & $\mathbf{0 . 9 9}$ & $\mathbf{0 . 9 1}$ & $\mathbf{0 . 8 4}$ & $\mathbf{0 . 9 9}$ \\
\hline
\end{tabular}

HR: Hazard ratio; CI: Confidence interval; bold indicates statistical significance $(p<0.05)$.

Population density appeared to be a protective factor, while a higher percentage of persons with university degrees and unemployment rates (the latter only significant for cases, not deaths) increased the risk. 
1. Innere Stadt 13. Hietzing
$\begin{array}{ll}\text { 2. Leopoldstadt } & \text { 14. Penzing } \\ \text { 3. Landstrasse } & \text { 15. Rudolfsh.-F. } \\ \text { 4. Wieden } & \text { 16. Ottakring } \\ \text { 5. Margareten } & \text { 17. Hernals } \\ \text { 6. Mariahilf } & \text { 18. Währing } \\ \text { 7. Neubau } & \text { 19. Döbling } \\ \text { 8. Josefstadt } & \text { 20. Brigittenau } \\ \text { 9. Alsergrund } & \text { 21. Floridsdorf } \\ \text { 10. Favoriten } & \text { 22. Donaustadt } \\ \text { 11. Simmering } & \text { 23. Liesing } \\ \text { 12. Meidling } & \end{array}$

$\operatorname{PM} 10\left(\mu \mathrm{g} / \mathrm{m}^{3}\right)$
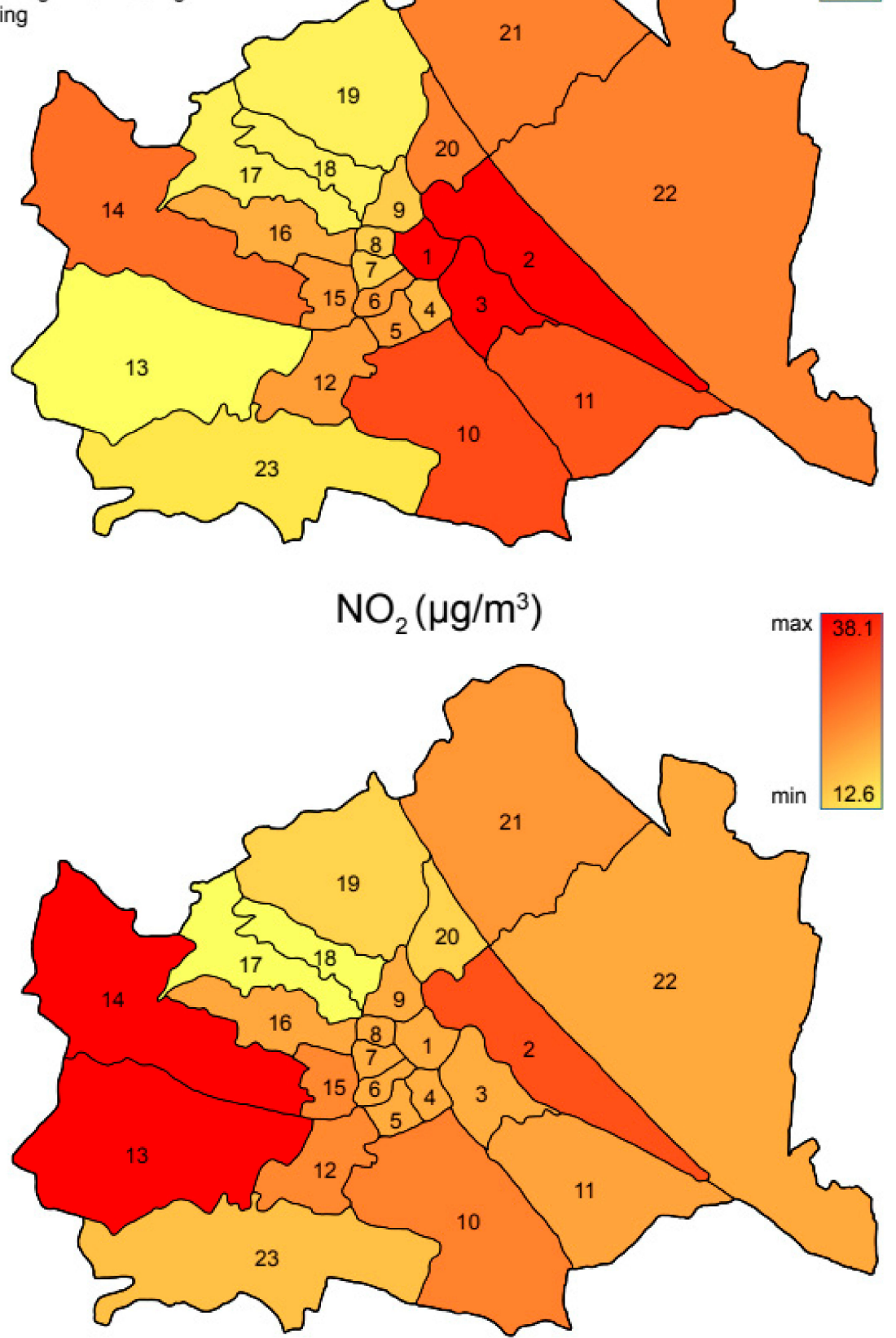

Figure 2. Map of Vienna districts with color-coded indication of mean annual airborne particulate matter particles smaller than $10 \mu \mathrm{m}, \mathrm{PM} 10$, (top), and $\mathrm{NO}_{2}$, (bottom) in $\mu \mathrm{g} / \mathrm{m}^{3}$. 


\section{Discussion}

The city of Vienna maintains a dense air quality monitoring network that has been used to examine health impacts of air pollution before [18]. The density of pollution-monitoring stations allows for an analysis of air pollution effects on COVID-19 infections and deaths on the basis of rather small urban areas. Data analysis was facilitated by reduced individual movements of inhabitants among districts during the individual ("stay-at-home" order) and economic lockdown of Austria between 16 March 2020, and the middle of May [19], as schools and most shops were closed, office workers were encouraged to work in home offices, and public transport systems were limited.

We found increased risks of being diagnosed with COVID-19 and of dying from that disease with increasing concentrations of air pollutants $\left(\mathrm{PM10}, \mathrm{NO}_{2}\right)$ in the home district averaged over the year 2019. An association between air pollution and risk of respiratory infections has been reported before [20-22] and does have some biological plausibility. Indeed, both short-term and long-term impacts of air pollution on risk and severity of SARS-CoV-2 infection are conceivable. For a short-term association, several possible mechanisms have been proposed. There could be a direct interaction between air pollutants and the virus in the atmosphere. Virus attached to particulates could be protected from UV radiation degradation [23], ozone [24], or other environmental factors, thus prolonging the viability of the virus in the environment. Particulates could serve as carriers of the virus, enhancing the deposition of the virus in the lung [25]. Particulates and irritant gases could affect the mucous membranes of the respiratory tract, rendering the cells more vulnerable to infection. While these mechanisms would mostly act around the time of infection, and also during the incubation period and early stages of the disease, damage to the mucous membranes could lead to a more severe disease outcome. Chronic exposure to air pollution is a known risk factor for respiratory diseases [26-28] such as emphysema and bronchial obstruction through remodeling of lung tissues. These chronic respiratory diseases could render a person more susceptible to infection and certainly are risk factors for a more severe course of the disease in case of an infection.

Studies also support the hypothesis that air pollution induces overexpression of ACE-2 [9,10,29]. Both air pollution and COVID-19 can cause systemic disease effects, and therefore, a combined effect also on mortality risk is plausible.

Similar findings were reported in other studies. Acute responses were analyzed by Zhu et al. [30]. They found (data of 120 cities) that a $10 \mu \mathrm{g} / \mathrm{m}^{3}$ increase (lag0-14) in PM2.5, PM10, $\mathrm{NO}_{2}$, and $\mathrm{O}_{3}$ was associated with a $2.24 \%$ (95\% CI: 1.02 to 3.46$), 1.76 \%$ (95\% CI: 0.89 to 2.63 ), $6.94 \%$ (95\% CI: 2.38 to 11.51 ), and $4.76 \%$ (95\% CI: 1.99 to 7.52 ) increase in the daily counts of confirmed cases, respectively.

US data were analyzed by Wu et al. [31]. COVID-19 death counts for more than 3000 counties in the United States were related to long-term average PM2.5 adjusted for 20 potential confounding factors. An increase of $1 \mu \mathrm{g} / \mathrm{m}^{3}$ in $\mathrm{PM}_{2.5}$ was associated with an $8 \%$ increase in the COVID-19 death rate. It was concluded that a "small increase in long-term exposure to PM2.5 leads to a large increase in the COVID-19 death rate".

While an air-pollution-dependent increase in mortality related to an infection of the lung may be expected, the correlation with case incidence may appear less obvious. However, a link between infection vulnerability and air quality has already been postulated for the 1952 London smog; numerous reports have confirmed these findings since, while the exact mechanisms are still unknown [32].

Pansini and Fornacca [33] showed higher rates of SARS-CoV-2 infections in areas with high PM2.5, $\mathrm{NO}_{2}$, and CO levels (China, Italy, US). The relationship between poor air quality and COVID-19 incidence and mortality was strongest in Italy. The analyses of Fattorini and Regoli [34] revealed that long-term exposure to major pollutants $\left(\mathrm{NO}_{2}, \mathrm{O}_{3}, \mathrm{PM}_{2.5}, \mathrm{PM}_{10}\right)$ significantly correlated with cases of COVID-19 in up to 71 Italian provinces. They underlined that besides current concentrations, the chronicity of exposure may influence the exceptional variability of SARS-CoV-2 infection frequency in Italy.

The given epidemiological setting does not allow for a clear separation between effects of acute and of chronic exposure. A person living in a district with higher air pollution concentration in 
2019 will, on average, likely also more often experience higher exposure levels on any single day in 2020. Examining the temporal course of effects in a time-series analysis would in principle allow for disentangling the contribution of acute and chronic exposures. However, this would require a substantial variation in daily concentrations over the period of study. This was not the case for the rather short period of analysis in our case. Furthermore, the temporal course of the number of daily cases was heavily influenced by measures on the individual and on the whole society's level to curb the epidemic. The lockdown led to a reduction in air pollution [35,36]; therefore, we focused on chronic effects and the air quality data of the preceding year. We are pretty confident that the year 2019 was representative, in that areas with higher air pollution levels in 2019 had higher levels also in the previous years. Absolute values changed between years, with generally a declining trend for both pollutants in the last 10 years or longer. However, the ranking of districts remained fairly stable. Examining longer time periods would also only lead to spurious improvements in exposure assessment. We might know better the longer-term concentration in each district. However, for our COVID patients, we only know their recent address. The farther back the pollution data, the less certain their place of living is.

As we aimed to test the hypothesis that chronic exposure leads to changes in the airways that render airways more susceptible to viral infection, we think that average exposure, expressed as annual mean levels, is the best descriptor of chronic exposure. Examining multiple sets of parameters would only lead to the statistical problem of multiple testing.

A model making use of spatial variation in exposure seems more viable and has also been applied by previous studies on air pollution and COVID-19 risk. These previous studies examined case numbers per population numbers, while our study looked at case numbers per person time. Nevertheless, in a separate paper, we have attempted to also investigate the temporal association between air pollution and COVID-19 cases in Vienna (submitted elsewhere).

Researchers have long been struggling with the fact that in experimental studies in humans or animals, health effects started to be observed at rather high exposure levels, while in epidemiological research, clear associations were already visible at much lower levels. Different explanations have been brought forward for that apparent discrepancy [37]: Experimental human or animal studies usually apply small sample sizes. Therefore, these studies might lack the necessary power to detect subtle effects. In the experimental setting, often a very homogeneous group is exposed. In real-life settings, exposed people display a large variability in individual susceptibility that is not captured by the experimental setting. However, even if susceptible groups were investigated, effects were typically seen at much higher levels. More likely, the discrepancy between experimental and epidemiological findings is due to the experiments typically investigating a single pollutant, while under real-world conditions, people are exposed consecutively or simultaneously to multiple factors. An infectious agent in combination with air pollutants might serve as a good model of such a combined exposure.

We initially expected a more pronounced spread of the virus in the more densely populated districts. To our surprise, the opposite was the case. However, a recent study from 913 US metropolitan counties also observed a protective effect of population density, at least for COVID-19 mortality [38]. It remains to be observed whether people living in denser areas maybe pay more attention to self-protection measures such as keeping minimum distance or wearing masks. In the case of Vienna, an additional cause might also lay within the fact that densely inhabited areas (districts 6-8, 15) are located within the inner city, consisting of mostly residential areas, whereas in outer districts, industry and wasteland prevail, lowering overall density. However, population density still seems to remain a factor worth investigating, also representing an indicator for socioeconomic status. Hence, a study focusing on population density alongside other socioeconomic indicators is in preparation.

In addition, the observation of both districts with a higher percentage of persons with unemployment (for COVID-19 incidence) and with a university degree (for both incidence and mortality) deserves further comments. As Villeneuve and Goldberg [12] have pointed out, communities with a better socioeconomic status might have better access to health care, ensuring a higher testing 
rate. This would lead to a spurious increase in case numbers in richer districts, but not necessarily to an increase in mortality. We propose that especially in the initial phase of an epidemic, population segments with higher income, which are also often better-connected and more mobile, could have an increased risk of infection. In the later stages of an epidemic, crowding and poor access to health care might tip the balance. We concentrated on the early stage of the epidemic on purpose because this included the first lockdown where mobility between districts also was reduced to a minimum. However, mobility could still have differed between social strata. COVID-19 cases and mortality in districts might also be influenced by the presence of large retirement homes and of clusters in the homes.

Unfortunately, the database does not allow for stratified analyses and the inclusion of additional potential confounders. Thus, we could not control for possible individual confounding factors but only included area-level factors in our analysis. However, we are confident that this analysis adds additional input to the ongoing discussion on air pollution and infectious diseases.

\section{Conclusions}

Even in a single large city with local variation in air pollution we found an association between chronic exposure to increased levels of $\mathrm{NO}_{2}$ and $\mathrm{PM}_{10}$, and COVID-19 incidence and mortality. The daily hazard was about $40 \%$ higher both for incidence and for death from COVID-19 if PM $_{10}$ was above $20 \mu \mathrm{g} / \mathrm{m}^{3}$. $\mathrm{NO}_{2}$ was an independent risk factor for both incidence and mortality, and especially was found to elevate the hazard for daily deaths by more than $70 \%$. Some evidence has already indicated that SARS-CoV-2 infection and mortality are influenced by air pollution, maybe due to the chronic airway impairment it induces. That such a relationship can also be found in a city with a rather limited exposure gradient and one that has experienced low numbers of infection is surprising and points to a greater impact of air pollution on respiratory infection than previously assumed.

Author Contributions: Conceptualization, M.K. and H.-P.H.; methodology, M.K.; data curation, H.-P.H. and M.M.; writing_original draft preparation, H.M. and P.W.; writing—review and editing, L.W., M.P. and K.L.; visualization, M.P. All authors have read and agreed to the published version of the manuscript.

Funding: This research received no external funding.

Conflicts of Interest: The authors declare no conflict of interest.

\section{References}

1. Ciencewicki, J.; Jaspers, I. Air pollution and respiratory viral infection. Inhal. Toxicol. 2007, 19, 1135-1146. [CrossRef] [PubMed]

2. Domingo, J.L.; Rovira, J. Effects of air pollutants on the transmission and severity of respiratory viral infections. Environ. Res. 2020, 187, 109650. [CrossRef] [PubMed]

3. Cui, Y.; Zhang, Z.-F.; Froines, J.; Zhao, J.; Wang, H.; Yu, S.-Z.; Detels, R. Air pollution and case fatality of SARS in the People's Republic of China: An ecologic study. Environ. Health 2003, 2, 15. [CrossRef]

4. Cai, Q.-C.; Lu, J.; Xu, Q.-F.; Guo, Q.; Xu, D.-Z.; Sun, Q.-W.; Yang, H.; Zhao, G.-M.; Jiang, Q.-W. Influence of meteorological factors and air pollution on the outbreak of severe acute respiratory syndrome. Public Health 2007, 121, 258-265. [CrossRef] [PubMed]

5. Kan, H.-D.; Chen, B.-H.; Fu, C.-W.; Yu, S.-Z.; Mu, L.-N. Relationship between ambient air pollution and daily mortality of SARS in Beijing. Biomed. Environ. Sci. 2005, 18, 1-4. [PubMed]

6. Conticini, E.; Frediani, B.; Caro, D. Can atmospheric pollution be considered a co-factor in extremely high level of SARS-CoV-2 lethality in Northern Italy? Environ. Pollut. 2020, 261, 114465. [CrossRef]

7. Ogen, Y. Assessing nitrogen dioxide $\left(\mathrm{NO}_{2}\right)$ levels as a contributing factor to coronavirus (COVID-19) fatality. Sci. Total Environ. 2020, 726, 138605. [CrossRef]

8. Stieb, D.M.; Evans, G.J.; To, T.M.; Jeffrey Brook, R.; Burnett, R.T. An ecological analysis of long-term exposure to PM2.5 and incidence of COVID-19 in Canadian health regions. Environ. Res. 2020, 191, 110052. [CrossRef] 
9. Borro, M.; Di Girolamo, P.; Gentile, G.; De Luca, O.; Preissner, R.; Marcolongo, A.; Ferracuti, S.; Simmaco, M. Evidence-Based Considerations Exploring Relations between SARS-CoV-2 Pandemic and Air Pollution: Involvement of PM2.5-Mediated Up-Regulation of the Viral Receptor ACE-2. Int. J. Environ. Res. Public Health 2020, 17, 5573. [CrossRef]

10. Comunian, S.; Dongo, D.; Milani, C.; Palestini, P. Air Pollution and Covid-19: The Role of Particulate Matter in the Spread and Increase of Covid-19's Morbidity and Mortality. Int. J. Environ. Res. Public Health 2020, 17, 4487. [CrossRef]

11. Copat, C.; Cristaldi, A.; Fiore, M.; Grasso, A.; Zuccarello, P.; Signorelli, S.S.; Conti, G.O.; Ferrante, M. The role of air pollution (PM and $\mathrm{NO}_{2}$ ) in COVID-19 spread and lethality: A systematic review. Environ. Res. 2020, 191, 110129. [CrossRef] [PubMed]

12. Villeneuve, P.J.; Goldberg, M.S. Methodological Considerations for Epidemiological Studies of Air Pollution and the SARS and COVID-19 Coronavirus Outbreaks. Environ. Health Perspect 2020, 128, 9. [CrossRef]

13. Statistik Austria (2020). Available online: https://www.statistik.at (accessed on 5 October 2020).

14. City of Vienna (2020). Available online: https://www.wien.gv.at/umwelt/luft/messstellen/ (accessed on 5 October 2020).

15. Schreier, S.F.; Richter, A.; Burrows, J.P. Near-surface and path-averaged mixing ratios of $\mathrm{NO}_{2}$ derived from car DOAS zenith-sky and tower DOAS off-axis measurements in Vienna: A case study. Atmos. Chem. Phys. 2019, 19, 5853-5879. [CrossRef]

16. Rocklöv, J.; Sjödin, H. High population densities catalyse the spread of COVID-19. J. Travel Med. 2020, 27, taaa038. [CrossRef] [PubMed]

17. De Lusignan, S.; Dorward, J.; Correa, A.; Jones, N.; Akinyemi, O.; Amirthalingam, G.; Andrews, N.; Byford, R.; Dabrera, G.; Elliot, A.; et al. Risk factors for SARS-CoV-2 among patients in the Oxford Royal College of General Practitioners Research and Surveillance Centre primary care network: A cross-sectional study. Lancet Infect. Dis. 2020, 20, 1034-1042. [CrossRef]

18. Moshammer, H.; Poteser, M.; Kundi, M.; Lemmerer, K.; Weitensfelder, L.; Wallner, P.; Hutter, H.-P. Nitrogen-Dioxide Remains a Valid Air Quality Indicator. Int. J. Environ. Res. Public Health 2020, 17, 3733. [CrossRef] [PubMed]

19. Moshammer, H.; Poteser, M.; Lemmerer, K.; Wallner, P.; Hutter, H.-P. Time Course of COVID-19 Cases in Austria. Int. J. Environ. Res. Public Health 2020, 17, 3270. [CrossRef]

20. Croft, D.P.; Zhang, W.; Lin, S.; Thurston, S.W.; Hopke, P.K.; Masiol, M.; Squizzato, S.; van Wijngaarden, E.; Utell, M.J.; Rich, D.Q. The Association between Respiratory Infection and Air Pollution in the Setting of Air Quality Policy and Economic Change. Ann. Am. Thorac. Soc. 2019, 16, 321-330. [CrossRef]

21. Horne, B.D.; Joy, E.A.; Hofmann, M.G.; Gesteland, P.H.; Cannon, J.B.; Lefler, J.S.; Blagev, D.P.; Korgenski, E.K.; Torosyan, N.; Hansen, G.I.; et al. Short-Term Elevation of Fine Particulate Matter Air Pollution and Acute Lower Respiratory Infection. Am. J. Respir. Crit. Care Med. 2018, 198, 759-766. [CrossRef]

22. Faustini, A.; Stafoggia, M.; Colais, P.; Berti, G.; Bisanti, L.; Cadum, E.; Cernigliaro, A.; Mallone, S.; Scarnato, C.; Forastiere, F. Air pollution and multiple acute respiratory outcomes. Eur. Respir. J. 2013, 42, 304-313. [CrossRef]

23. Sagripanti, J.-L.; Lytle, C.D. Inactivation of influenza virus by solar radiation. Photochem. Photobiol. 2007, 83, 1278-1282. [CrossRef] [PubMed]

24. Wolcott, J.A.; Zee, Y.C.; Osebold, J.W. Exposure to ozone reduces influenza disease severity and alters distribution of influenza viral antigens in murine lungs. Appl. Environ. Microbiol. 1982, 44, 723-731. [CrossRef] [PubMed]

25. Setti, L.; Passarini, F.; De Gennaro, G.; Barbieri, P.; Perrone, M.G.; Borelli, M.; Palmisani, J.; Di Gilio, A.; Torboli, V.; Fontana, F.; et al. SARS-Cov-2RNA found on particulate matter of Bergamo in Northern Italy: First evidence. Environ. Res. 2020, 188, 109754. [CrossRef] [PubMed]

26. Doiron, D.; De Hoogh, K.; Probst-Hensch, N.; Fortier, I.; Cai, Y.; De Matteis, S.; Hansel, A.L. Air pollution, lung function and COPD: Results from the population-based UK Biobank study. Eur. Respir. J. 2019, 54, 1802140. [CrossRef] [PubMed]

27. Sunyer, J. Urban air pollution and chronic obstructive pulmonary disease: A review. Eur. Respir. J. 2001, 17, 1024-1033. [CrossRef] [PubMed] 
28. Wang, M.; Aaron, C.P.; Madrigano, J.; Hoffman, E.A.; Angelini, E.; Yang, J.; Laine, A.; Vetterli, T.M.; Kinney, P.L.; Sampson, P.D.; et al. Association between long-term exposure to ambient air pollution and change in quantitatively assessed emphysema and lung function. JAMA 2019, 322, 546-556. [CrossRef] [PubMed]

29. Frontera, A.; Cianfanelli, L.; Vlachos, K.; Landoni, G.; Cremona, G. Severe air pollution links to higher mortality in COVID-19 patients: The "double-hit" hypothesis. J. Infect. 2020, 81, 255-259. [CrossRef]

30. Zhu, Y.; Xie, J.; Huang, F.; Cao, L. Association between short-term exposure to air pollution and COVID-19 infection: Evidence from China. Sci. Total Environ. 2020, 727, 138704. [CrossRef]

31. Wu, X.; Nethery, R.C.; Sabath, B.M.; Braun, D.; Dominici, F. Exposure to air pollution and COVID-19 mortality in the United States: A nationwide cross-sectional study. medRxiv 2020. [CrossRef]

32. Grigg, J. Air Pollution and Respiratory Infection: An Emerging and Troubling Association. Am. J. Respir. Crit. Care Med. 2018, 198, 700-701. [CrossRef]

33. Pansini, R.; Fornacca, D. Initial evidence of higher morbidity and mortality due to SARS-CoV-2 in regions with lower air quality. medRxiv 2020. [CrossRef]

34. Fattorini, D.; Regoli, F. Role of the chronic air pollution levels in the Covid-19 outbreak risk in Italy. Environ. Pollut. 2020, 264, 114732. [CrossRef] [PubMed]

35. Zhang, R.; Zhang, Y.; Lin, H.; Feng, X.; Fu, T.-M.; Wang, Y. NOx emission reduction and recovery during COVID-19 in East China. Atmosphere 2020, 11, 433. [CrossRef]

36. Environment Agency Austria. Impact of Lockdown Measures on Air Quality in Austria. Available online: https://www.umweltbundesamt.at/en/news-reports/news-eaa/en-news-2020/news-en-200415 (accessed on 19 November 2020).

37. WHO Europe. Review of Evidence on Health Aspects of Air Pollution-REVIHAAP Project: Final Technical Report. Available online: https://www.euro.who.int/_data/assets/pdf_file/0004/193108/REVIHAAP-Finaltechnical-report-final-version.pdf (accessed on 5 October 2020).

38. Hamidi, S.; Sabouri, S.; Ewing, R. Does Density Aggravate the COVID-19 Pandemic? J. Am. Plan. Assoc. 2020, 86, 495-509. [CrossRef]

Publisher's Note: MDPI stays neutral with regard to jurisdictional claims in published maps and institutional affiliations.

(C) 2020 by the authors. Licensee MDPI, Basel, Switzerland. This article is an open access article distributed under the terms and conditions of the Creative Commons Attribution (CC BY) license (http://creativecommons.org/licenses/by/4.0/). 